American Journal of Applied Sciences 9 (8): 1259-1267, 2012

ISSN 1546-9239

(C) 2012 Science Publications

\title{
Information and Communication Technology Innovation for Construction Site Management
}

\author{
Nuruddeen Usman and Ilias Said \\ School of Housing, Building and Planning, \\ University Sains Malaysia, 11800 USM Pulau Pinang, Malaysia
}

\begin{abstract}
Problem statement: The industrialization of the world from whole to site as a result of technological innovation made many industries adopting Information and Communication Technology (ICT) for processing of all their activities from inception to completion, especially in the developed nations. But, the developing nations appear to make sluggish progress towards ICT adoption due to apprehensiveness that their fraudulent activities can easily be traced. Approach: The purpose of this study was to evaluate the contractor's perception toward ICT innovation acceptance for construction site management and the effectiveness of the innovation. A 519 questionnaire survey was employed for the data collection, while SPSS version 17.0 was used for the descriptive statistic and factorial analysis of the data. Results: The findings show ICT innovation was effective for site management but there were positive and negative factors that affect the ICT innovation based on the contractors view. Conclusion: By evaluating the ICT innovation, empirical evidence has been provided for the "wait and see contractors' to adopt ICT in construction site management and by making adequate provisions against the negative factors.
\end{abstract}

Key words: Information and Communication Technology (ICT), Principal Components Analysis (PCA), Exploratory Factor Analysis (EFA)

\section{INTRODUCTION}

Daily human needs is not all what is necessary to live; but people need to know what is happening around them and in the world at large, especially construction projects that are carried out at different locations simultaneously, without exchanging information people would be extremely lonely, which may result in time and cost overrun. Today there are many means of communication starting from paper and pen, books, encyclopedias, magazines, newspapers, post offices, transistor radio, television sets, portable sound or video recorders, telephones, cell phones, personal computers and internet. Some of them came only in the decade, some during the last century, some several hundred or thousand years ago.

Early communications: The first means of communication was the human voice. But in 1,500BC writing was invented in china, while 3,100BC in Egypt then 3,300BC in Iraq. The next step was the invention of alphabet in Israel and Lebanon about 1,600BC. In the ancient world many civilizations had efficient postal systems to deliver messages to the part of their empires using relays of horses and they wrote on papyrus or parchment. However, the Chinese invented paper about 200BC. The next major improvement in communications was the invention of printing. The Chinese invented printing with blocks in the 6th century $\mathrm{AD}$, but the first known printed book was the Diamond Sutra of 686pp. In Europe in the mid of 15th century Johannes Gutenberg invented the printing press, which made books much cheaper and allowed newspapers to be invented. William Caxton introduced the printing press into England in 1476. While European monarchs set-up postal services to carry their messages, in France Louis XI founded one in 1477 and in England Henry VIII created the royal mailing in 1512 . Then in $16^{\text {th }}$ century pencil was invented in England and described in 1565.

Modern communications: Telegraph was invented in 1837. A cable was laid across the channel in 1851 and after 1866 it was possible to send messages across the Atlantic. Meanwhile the first fax machine was invented in 1843. A scot Alexander graham bell invented the telephone in 1876. The first successful typewriter was made in 1874 and the first successful fountains pen was made in 1884. In 1829 Louis Braille invented an embossed typeface for the blind and in 1837 Isaac pitman invented shorthand. In 1901 Marconi sent a

Corresponding Author: NuruddeenUsman, School of Housing, Building and Planning, University Sains Malaysia,

11800 USM Pulau Pinang, Malaysia 
Am. J. Applied Sci., 9 (8): 1259-1267, 2012

radio message across the Atlantic. Radio broadcasting began in Britain in 1922 when the BBC was formed. Television was invented in 1926 by John Logie Baird. In 1962 the first telecommunications satellite, Telstar was launched. Satellite television began in Britain in 1989. Telephone became common in 1970s. The first mobile call in Britain was made in 1985, the first commercial text was sent in 1992. In 1872 Lord Kelvin develops analogue computer to predict tides and in 1941 Konrad Zuse produces digital computer the $Z_{3}$ in Germany. In 1948 Von Neumann develops computer memory system. While in 1957 IBM unveils FORTRAN programming language. In 1965 the first wide-area computer network was created in California and Massachusetts by Lawrence Roberts. The internet developed in the 1970s, emerges in 1983 and did not become accessible until 1991. In 1971 engineers at Intel invent the microprocessor. The first email was sent in 1972 by Ray Tomlinson using @ in address and today is the most popular methods of communication. In 1973 a local area network Ethernet is developed at Xerox PARC. The first personal computer was introduced in 1974. IBM introduces personal computer using Microsoft operating system in 1981. High-school students create first computer virus in 1982. Microsoft introduces its first version of windows in 1985. 1989 Microsoft introduces new product Microsoft office. In 1990 Alan Entage creates the Archie, the first tool for searching web files. In 1991 worldwide web begins, 1992 computer servers were introduced. In 1995 Microsoft introduces windows95. Larry page and Sergey Brin found Google while at Stanford. In 2001 Wikipedia, an online encyclopaedia was launched. MySpace is created by eUniverse employees in 2003. Also in 2005 YouTube is launched.

Innovation in construction: Innovations in the construction industry refers to the process of development, distribution and application of technologies a new or improved product, process or service and knowledge with the purpose to improve productivity and to suit the customer's requirements (Egmond and Ligny, 2005). Toole (1998) defines innovation process as application of technology that is new to an organization and that significantly improves the design and construction by decreasing the cost, increasing the performance and improving the business process. Mottowa et al. (1999) emphasizes innovation in construction as the process through which new ideas turn into new components of constructed products that have economic, functional, or technological value. Construction presents important opportunities for innovation. Drucker (1993) emphasizes innovation as the application of knowledge to produce new knowledge.
Table 1: Models of innovations in construction

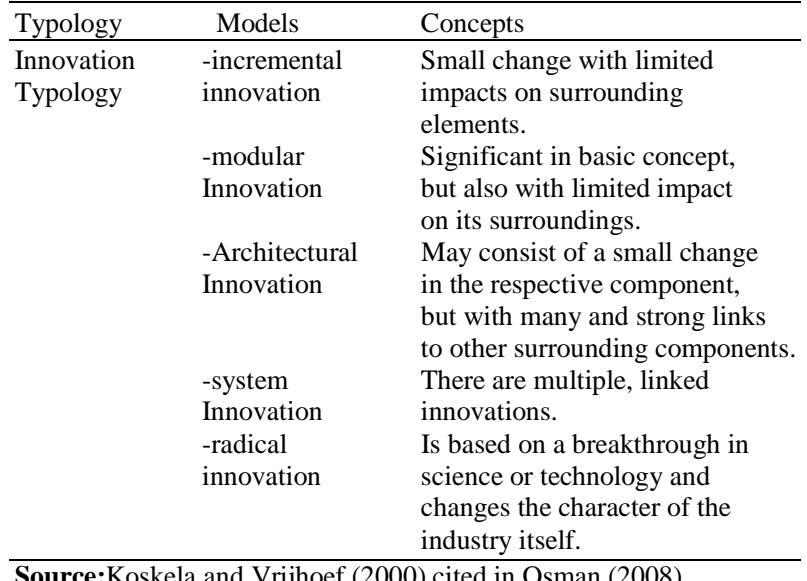

Source:Koskela and Vrijhoef (2000) cited in Osman (2008)

According to Osman (2008) innovation has been defined as the actual use of a non-trivial change and improvement in a process, product or system that is novel to the institution developing the change. Koskela and Vrijhoef (2000) cited in Osman (2008) summarizes several typologies of innovations models in construction industry as incremental, modular, architectural, system and radical innovations as shown Table 1.

Therefore, the aim of this study is to evaluate the contractor's perception on ICT innovation for construction site management in Nigeria with a view to provide practical evidence of the factors that affects its application. The result will help contractors at the lower category to develop strategies for ICT implementation.

\section{MATERIALS AND METHODS}

The research method used in this study in order to achieve the set objective and to answer the research question is field study using questionnaire. The study area for this research is three (3) zones out of six (6) geo-political zones of Nigeria including; north-west, south-west and south-east. In addition, two (2) states were selected from each zone based on the population including; Kano and Kaduna (from the north-west), Lagos and Oyo (from the south-west) and Rivers and Anambra (from the south-east). Likewise, Hausa, Yoruba and Igbo settings are considered in accordance to the Nigerian constitution and their population.

Furthermore, to ensure equal treatment in this study disproportionate stratified random sampling is preferred over proportionate sampling (Newman and Sabherwal, 1996), because the research was carried out at different zones and among different languages and beliefs, so variability are suspected within a particular stratum. Also the contractor's construction industries 
considered are those that belong to the category A (up to $\mathrm{N} 2$ million), $\mathrm{B}$ ( $\mathrm{N} 2$ million - $\mathrm{N} 25$ million), C (N25million - N100million) and D (Above N100million), of the Federal Registration Board of Nigeria. Statistical methods were used for the data analysis by employing a computer based software program SPSS 17.0 for windows. The descriptive statistics were explained based on the mean values of results obtained by Likert scale qualification, with 1.00 $=$ no effect to $5.00=$ very effective. The considered no effect-very effective levels are shown in Table 2.

In addition, for the data analysis SPSS version 17.0(Pallant, 2011) was used, to test the reliability of the data cronbach alpha was used in order to know whether the data is reliable or not, with a normality plot and normal P-P value plot to confirm the normality. Exploratory Factor Analysis (EFA) was also employed to assess the suitability of the data for factor analysis and to identify the positive and negative factors under consideration. A Principal Component Analysis (PCA) was used to extract the factors, followed by the number of factors to be retained was guided by three decision rules: Eigenvalue above 1, Screeplot and Parallel analysis (Horn, 1965). Furthermore, suitability of the data for factor analysis was assessed by inspection of the correlation matrix for evidence of coefficients greater than 0.3 are many, when few factor analysis is not appropriate (Tabachnick and Fidell, 2007), also the Bartletts test of sphericity should be significant $(\mathrm{p}<0.05)$ for factor analysis to be considered appropriate, the KMO index ranges from $0-1$, with 0.6 suggested as the minimum value for a good factor analysis. Factor extraction was also used to determine the factors that have highest effect among the items using principal component analysis. Kaiser's criterion or eigenvalue rule (eigenvalue of 1 or more are retained) and parallel analysis (Choi et al., 2001; Stober 1998) are used in order to identify correct components to retain. Factors are rotated in order to get the pattern of loadings for easy interpretation using oblique approach (direct oblimin).

\section{RESULTS}

The results obtained from the descriptive analyses are presented in Table 2-18 and Fig. 1-3.

Table 2: Considered no effect-very effective levels of results

\begin{tabular}{ll}
\hline Likert scale & Effect level \\
\hline $1.00-1.50$ & No effect \\
$1.50-2.50$ & Minor effect \\
$2.50-3.50$ & Moderate effect \\
$3.50-4.50$ & Effective \\
$4.50-5.00$ & Very effective \\
\hline
\end{tabular}

Table 3: Years of experience of the respondents

\begin{tabular}{lcr}
\hline Years & Frequency & Percentage \\
\hline 1(1-5yrs) & 69 & 23.5 \\
2(6-10yrs) & 98 & 33.3 \\
3(11-20yrs) & 92 & 31.3 \\
4(21-30yrs) & 26 & 8.8 \\
5(over 30yrs) & 9 & 3.1 \\
Total & 294 & 100.0 \\
\hline
\end{tabular}

Table 4: Category of the respondent's contractor

\begin{tabular}{lrr}
\hline Contractors & Frequency & Percentage \\
\hline $1(\mathrm{~A})$ & 6 & 2.0 \\
$2(\mathrm{~B})$ & 12 & 4.0 \\
$3(\mathrm{C})$ & 60 & 20.2 \\
$4(\mathrm{D})$ & 219 & 73.7 \\
Total & 297 & 100.0 \\
\hline
\end{tabular}

Table 5: Level of Education of the Respondents

\begin{tabular}{lcr}
\hline Qualification & Frequency & Percentage \\
\hline $1(\mathrm{PhD})$ & 25 & 8.4 \\
2(Msc) & 28 & 9.5 \\
3(Bsc) & 50 & 16.9 \\
4(Dip) & 107 & 36.1 \\
5(Cert) & 85 & 28.7 \\
6(S.L) & 1 & 0.3 \\
Total & 296 & 100.0 \\
\hline
\end{tabular}

Table 6: Number of Staff in the Industry

\begin{tabular}{lrr}
\hline Staff & Frequency & Percentage \\
\hline $1(<50)$ & 114 & 39.2 \\
$2(50-100)$ & 94 & 32.3 \\
$3(100-500)$ & 52 & 17.9 \\
$4(>500)$ & 31 & 10.7 \\
Total & 291 & 100.0 \\
\hline
\end{tabular}

Table 7: Summary item statistics

\begin{tabular}{|c|c|c|c|c|c|c|c|}
\hline & Mean & Minimum & Maximum & Range & $\begin{array}{l}\text { Maximum/ } \\
\text { Minimum }\end{array}$ & Variance & $\mathrm{N}$ of Items \\
\hline Item Means & 3.825 & 3.067 & 4.273 & 1.206 & 1.393 & 0.149 & 13 \\
\hline Inter-Item Correlations & 0.289 & -0.226 & 0.734 & 0.960 & -3.246 & 0.033 & 13 \\
\hline
\end{tabular}

Table 8: ANOVA

\begin{tabular}{llcrrr}
\hline & & Sum of squares & df & Mean square & F \\
\hline Between people & & 2021.501 & 281 & 7.194 & \\
Within people & Between Items & 504.618 & 12 & 42.052 & 34.685 \\
& Residual & 4088.151 & 3372 & 1.212 & 0.000 \\
Total & Total & 4592.769 & 3384 & 1.357 & \\
\hline
\end{tabular}

Grand Mean $=3.83$ 
Am. J. Applied Sci., 9 (8): 1259-1267, 2012

Table 9:Correlations

\begin{tabular}{|c|c|c|c|c|c|}
\hline & & Contractor A & Contractor B & Contractor C & Contractor D \\
\hline \multirow[t]{5}{*}{ Contractor A } & Pearson Correlation & 1.000 & -0.376 & $0.736^{* *}$ & $0.720^{* *}$ \\
\hline & Sig. (2-tailed) & & 0.206 & 0.004 & 0.006 \\
\hline & $\begin{array}{l}\text { Sum of Squares and } \\
\text { Cross-products }\end{array}$ & 2.827 & -0.798 & 2.007 & 1.610 \\
\hline & Covariance & 0.236 & -0.067 & 0.167 & 0.134 \\
\hline & $\mathrm{N}$ & 13.000 & 13.000 & 13.000 & 13.000 \\
\hline \multirow[t]{5}{*}{ Contractor B } & Pearson Correlation & -0.376 & 1.000 & 0.244 & 0.177 \\
\hline & Sig. (2-tailed) & 0.206 & & 0.421 & 0.563 \\
\hline & $\begin{array}{l}\text { Sum of Squares and } \\
\text { Cross-products }\end{array}$ & -0.798 & 1.596 & 0.500 & 0.297 \\
\hline & Covariance & -0.067 & 0.133 & 0.042 & 0.025 \\
\hline & $\mathrm{N}$ & 13.000 & 13.000 & 13.000 & 13.000 \\
\hline \multirow[t]{5}{*}{ Contractor C } & Pearson Correlation & $0.736^{* *}$ & 0.244 & 1.000 & $0.971^{* *}$ \\
\hline & Sig. (2-tailed) & 0.004 & 0.421 & & 0.000 \\
\hline & $\begin{array}{l}\text { Sum of Squares and } \\
\text { Cross-products }\end{array}$ & 2.007 & 0.500 & 2.627 & 2.094 \\
\hline & Covariance & 0.167 & 0.042 & 0.219 & 0.174 \\
\hline & $\mathrm{N}$ & 13.000 & 13.000 & 13.000 & 13.000 \\
\hline \multirow[t]{5}{*}{ Contractor D } & Pearson Correlation & $0.720^{* * *}$ & 0.177 & $0.971^{* *}$ & 1.000 \\
\hline & Sig. (2-tailed) & 0.006 & 0.563 & 0.000 & \\
\hline & $\begin{array}{l}\text { Sum of Squares and } \\
\text { Cross-products }\end{array}$ & 1.610 & 0.297 & 2.094 & 1.771 \\
\hline & Covariance & 0.134 & 0.025 & 0.174 & 0.148 \\
\hline & $\mathrm{N}$ & 13.000 & 13.000 & 13.000 & 13.000 \\
\hline
\end{tabular}

**: Correlation is significant at the 0.01 level (2-tailed).

Table 10: Reliability statistics

\begin{tabular}{lll} 
& Cronbach's & \\
Cronbach's & Alpha Based on & N Items \\
alpha & standardized & 13 \\
\hline 0.831 & items & 0.841 \\
\hline
\end{tabular}

Table 11: Correlation matrix

\begin{tabular}{|c|c|c|c|c|c|c|c|c|c|c|c|c|c|}
\hline Correlation & $\begin{array}{l}\text { Exposure } \\
\text { to ICT }\end{array}$ & $\begin{array}{l}\text { Knowledge } \\
\text { of ICT } \\
\text { concept }\end{array}$ & $\begin{array}{l}\text { Awarens } \\
\text { on benft } \\
\text { of ICT }\end{array}$ & $\begin{array}{l}\text { Lak of } \\
\text { knowledge } \\
\text { oprate ICT }\end{array}$ & $\begin{array}{l}\text { Speedy } \\
\text { storage of } \\
\text { inform }\end{array}$ & $\begin{array}{l}\text { Easy } \\
\text { retrieval } \\
\text { of inform }\end{array}$ & $\begin{array}{l}\text { Lak of } \\
\text { interest } \\
\text { on ICT } \\
\end{array}$ & $\begin{array}{l}\text { Operatnl } \\
\text { diffety } \\
\text { of ICT }\end{array}$ & $\begin{array}{l}\text { Security } \\
\text { features } \\
\text { of ICT }\end{array}$ & $\begin{array}{l}\text { Lak of } \\
\text { purposely } \\
\text { made ICT }\end{array}$ & $\begin{array}{l}\text { Inadqt } \\
\text { software of } \\
\text { constn site }\end{array}$ & $\begin{array}{l}\text { Irreqular } \\
\text { f power } \\
\text { supply }\end{array}$ & $\begin{array}{l}\text { Poor } \\
\text { telecom } \\
\text { infrstr } \\
\end{array}$ \\
\hline Exposure to ICT & 1.000 & 0.734 & 0.697 & 0.400 & 0.134 & 0.512 & 0.313 & 0.281 & 0.207 & 0.262 & 0.417 & 0.321 & 0.203 \\
\hline $\begin{array}{l}\text { Knowledge } \\
\text { of ICT concept }\end{array}$ & 0.734 & 1.000 & 0.719 & 0.477 & 0.182 & 0.398 & 0.300 & 0.276 & 0.211 & 0.246 & 0.339 & 0.305 & 0.158 \\
\hline $\begin{array}{l}\text { Awareness on } \\
\text { benft of ICT }\end{array}$ & 0.697 & 0.719 & 1.000 & 0.418 & 0.137 & 0.481 & 0.258 & 0.219 & 0.167 & 0.244 & 0.452 & 0.370 & 0.229 \\
\hline $\begin{array}{l}\text { Lak of knwdge } \\
\text { to oprate ICT }\end{array}$ & 0.400 & 0.477 & 0.418 & 1.000 & 0.197 & 0.385 & 0.393 & 0.453 & 0.338 & 0.291 & 0.378 & 0.245 & 0.166 \\
\hline $\begin{array}{l}\text { Speedy inform } \\
\text { storage of. }\end{array}$ & 0.134 & 0.182 & 0.137 & 0.197 & 1.000 & 0.107 & -0.010 & 0.150 & 0.244 & 0.116 & -0.184 & -0.203 & -0.181 \\
\hline $\begin{array}{l}\text { Easy retrieval } \\
\text { of inform }\end{array}$ & 0.512 & 0.398 & 0.481 & 0.385 & 0.107 & 1.000 & 0.465 & 0.310 & 0.225 & 0.153 & 0.371 & 0.267 & 0.212 \\
\hline $\begin{array}{l}\text { Lak of interest } \\
\text { on ICT }\end{array}$ & 0.313 & 0.300 & 0.258 & 0.393 & -0.010 & 0.465 & 1.000 & 0.584 & 0.303 & 0.223 & 0.365 & 0.314 & 0.268 \\
\hline $\begin{array}{l}\text { Operatnl diffcty } \\
\text { of ICT }\end{array}$ & 0.281 & 0.276 & 0.219 & 0.453 & 0.150 & 0.310 & 0.584 & 1.000 & 0.611 & 0.368 & 0.268 & 0.217 & 0.215 \\
\hline $\begin{array}{l}\text { Security features } \\
\text { of ICT }\end{array}$ & 0.207 & 0.211 & 0.167 & 0.338 & 0.244 & 0.225 & 0.303 & 0.611 & 1.000 & 0.437 & 0.219 & 0.149 & 0.129 \\
\hline $\begin{array}{l}\text { Lak of purposely } \\
\text { made ICT }\end{array}$ & 0.262 & 0.246 & 0.244 & 0.291 & 0.116 & 0.153 & 0.223 & 0.368 & 0.437 & 1.000 & 0.363 & 0.291 & 0.206 \\
\hline $\begin{array}{l}\text { Inadqt softwre } \\
\text { for constn site }\end{array}$ & 0.417 & 0.339 & 0.452 & 0.378 & -0.184 & 0.371 & 0.365 & 0.268 & 0.219 & 0.363 & 1.000 & 0.534 & 0.433 \\
\hline $\begin{array}{l}\text { Irreqular } \\
\text { power supply }\end{array}$ & 0.321 & 0.305 & 0.370 & 0.245 & -0.203 & 0.267 & 0.314 & 0.217 & 0.149 & 0.291 & 0.534 & 1.000 & 0.622 \\
\hline $\begin{array}{l}\text { Poor telecom } \\
\text { infrstr }\end{array}$ & 0.203 & 0.158 & 0.229 & 0.166 & -0.181 & 0.212 & 0.268 & 0.215 & 0.129 & 0.206 & 0.433 & 0.622 & 1.000 \\
\hline
\end{tabular}


Am. J. Applied Sci., 9 (8): 1259-1267, 2012

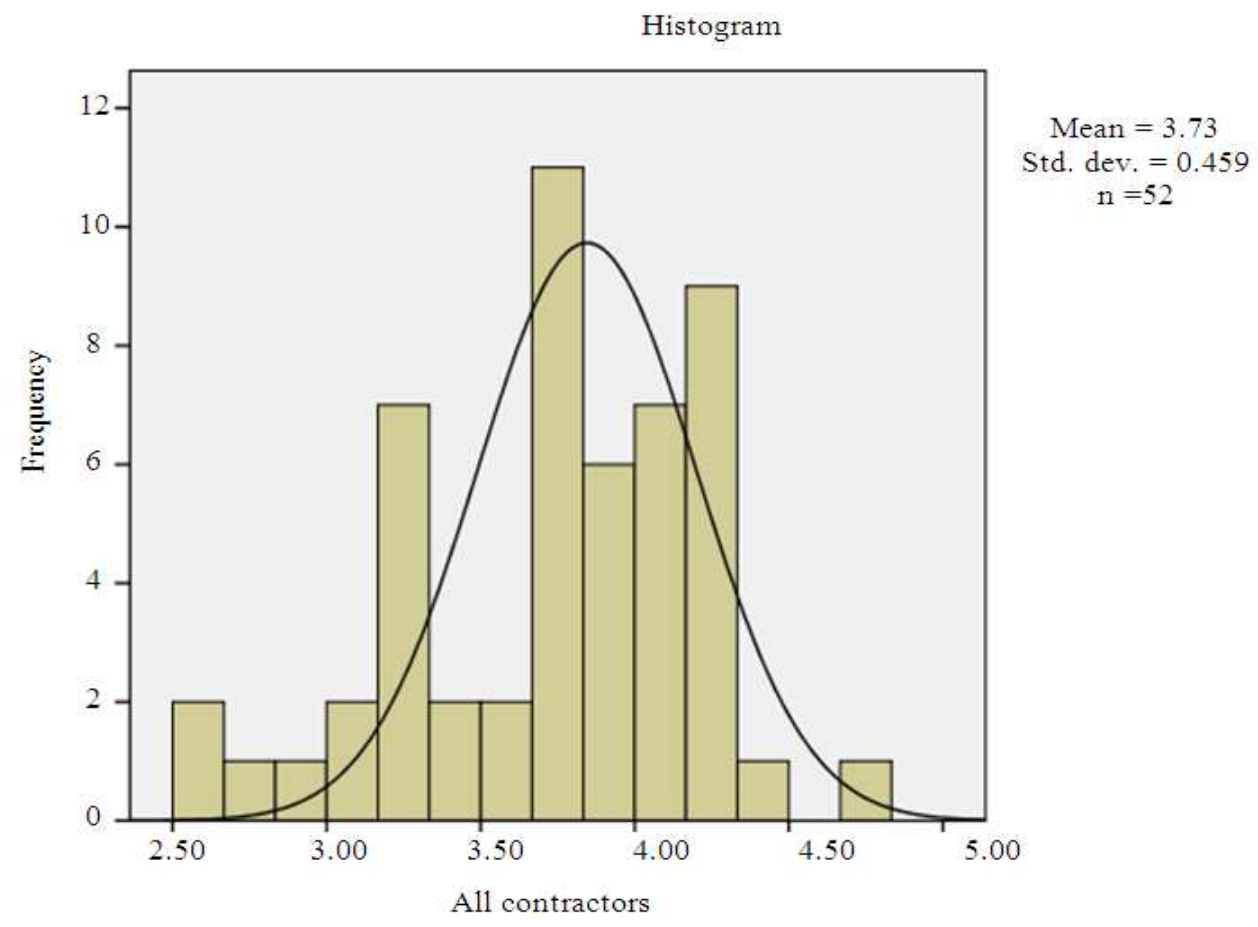

Fig. 1: Normality Distribution of the Data

Table 12: KMO and Bartlett's Test

\begin{tabular}{|c|c|c|}
\hline \multicolumn{2}{|c|}{ Kaiser-meyer-olkin measure of sampling adequacy. } & .827 \\
\hline \multirow[t]{3}{*}{ Bartlett's test of sphericity } & Approx. chi-square & 1582.847 \\
\hline & df & 78 \\
\hline & Sig. & .000 \\
\hline
\end{tabular}

Table 13: Total variance explained

\begin{tabular}{|c|c|c|c|c|c|c|c|}
\hline \multirow[b]{2}{*}{ Component } & \multicolumn{3}{|c|}{ Initial eigenvalues } & \multicolumn{3}{|c|}{ Extraction sums of squared loadings } & \multirow{2}{*}{$\begin{array}{l}\text { Rotation sums } \\
\text { of squared } \\
\text { Loadings }^{\mathrm{a}} \\
\text { Total }\end{array}$} \\
\hline & Total & $\%$ of Variance & Cumulative $\%$ & Total & $\%$ of Variance & Cumulative $\%$ & \\
\hline 1 & 4.808 & 36.988 & 36.988 & 4.808 & 36.988 & 36.988 & 4.026 \\
\hline 2 & 1.743 & 13.408 & 50.396 & 1.743 & 13.408 & 50.396 & 2.327 \\
\hline 3 & 1.544 & 11.877 & 62.273 & 1.544 & 11.877 & 62.273 & 3.422 \\
\hline 4 & 0.969 & 7.458 & 69.731 & & & & \\
\hline 5 & 0.707 & 5.436 & 75.166 & & & & \\
\hline 6 & 0.606 & 4.662 & 79.829 & & & & \\
\hline 7 & 0.584 & 4.495 & 84.324 & & & & \\
\hline 8 & 0.496 & 3.812 & 88.136 & & & & \\
\hline 9 & 0.405 & 3.119 & 91.255 & & & & \\
\hline 10 & 0.355 & 2.734 & 93.989 & & & & \\
\hline 11 & 0.290 & 2.228 & 96.218 & & & & \\
\hline 12 & 0.278 & 2.138 & 98.356 & & & & \\
\hline 13 & 0.214 & 1.644 & 100.000 & & & & \\
\hline
\end{tabular}

Extraction Method: Principal Component Analysis; ${ }^{a}$ : When components are correlated, sums of squared loadings cannot be added to obtain a total variance. 
Am. J. Applied Sci., 9 (8): 1259-1267, 2012

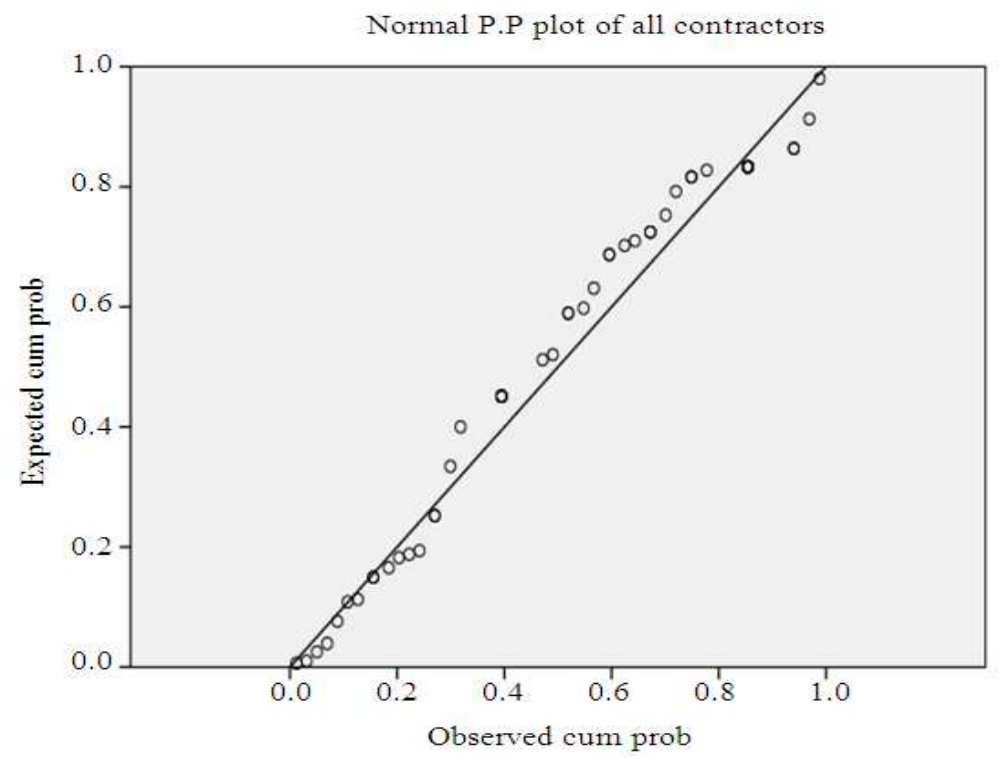

Fig. 2: Normal P-P plot of the data

Table 14: Component Matrix ${ }^{\mathrm{a}}$

\begin{tabular}{|c|c|c|c|}
\hline & \multicolumn{3}{|c|}{ Component } \\
\hline & 1 & 2 & 3 \\
\hline Exposure to ICT & 0.743 & 0.080 & -0.456 \\
\hline Awarens on benft of ICT & 0.731 & 0.017 & -0.498 \\
\hline Knwledge of ICT concept & 0.721 & 0.158 & -0.470 \\
\hline Inadqt softwre for constn site & 0.674 & -0.408 & 0.046 \\
\hline Lak of knwdge to oprate ICT & 0.668 & 0.238 & 0.024 \\
\hline Easy retrieval of inform & 0.649 & 0.058 & -0.177 \\
\hline Lak of interest on ICT & 0.627 & 0.007 & 0.303 \\
\hline Operatnl diffcty of ICT & 0.620 & 0.291 & 0.524 \\
\hline Irreqular power supply & 0.591 & -0.586 & 0.095 \\
\hline Lak of purposely made ICT & 0.515 & 0.088 & 0.354 \\
\hline Speedy storage of inform. & 0.124 & 0.735 & -0.092 \\
\hline Poor telecom infrstr & 0.470 & -0.598 & 0.213 \\
\hline Security features of ICT & 0.504 & 0.390 & 0.529 \\
\hline
\end{tabular}

Extraction Method: Principal Component Analysis. ${ }^{a}: 3$ components extracted.

Table 15: Pattern and structure matrix for Principal Component Analysis (PCA) with Oblimin Rotation

\begin{tabular}{|c|c|c|c|c|c|c|c|}
\hline \multirow[b]{2}{*}{ Item } & \multicolumn{3}{|c|}{ Pattern coefficients } & \multicolumn{3}{|c|}{ Structure coefficients } & \multirow[b]{2}{*}{ Communalities } \\
\hline & Component 1 & Component 2 & Component 3 & Component 1 & Component 2 & Component 3 & \\
\hline Awarens on benft of ICT & 0.917 & -0.059 & -0.126 & 0.875 & -0.219 & 0.273 & 0.782 \\
\hline Knwledge of ICT concept 0 & 0.905 & 0.073 & -0.047 & 0.870 & -0.095 & 0.327 & 0.765 \\
\hline Exposure to ICT & 0.895 & -0.010 & -0.055 & 0.874 & -0.175 & 0.327 & 0.766 \\
\hline Easy retrieval of inform & 0.578 & -0.069 & 0.152 & 0.656 & -0.203 & 0.408 & 0.456 \\
\hline $\begin{array}{l}\text { Lak of knwdge to } \\
\text { oprate ICT }\end{array}$ & 0.432 & 0.056 & 0.420 & 0.599 & -0.088 & 0.596 & 0.504 \\
\hline Poor telecom infrstr & 0.023 & -0.742 & 0.165 & 0.236 & -0.770 & 0.280 & 0.623 \\
\hline Irreqular power supply & 0.209 & -0.736 & 0.114 & 0.399 & -0.792 & 0.308 & 0.701 \\
\hline Speedy storage of inform. & 0.260 & 0.698 & 0.271 & 0.240 & 0.609 & 0.282 & 0.564 \\
\hline $\begin{array}{l}\text { Inadqt softwre for } \\
\text { constn site }\end{array}$ & 0.330 & -0.574 & 0.179 & 0.516 & -0.663 & 0.401 & 0.622 \\
\hline Operatnl diffcty of ICT & -0.047 & 0.009 & 0.883 & 0.327 & -0.107 & 0.861 & 0.744 \\
\hline Security features of ICT & -0.112 & 0.133 & 0.876 & 0.234 & 0.030 & 0.809 & 0.687 \\
\hline $\begin{array}{l}\text { Lak of purposely } \\
\text { made ICT }\end{array}$ & 0.014 & -0.122 & 0.595 & 0.291 & -0.210 & 0.618 & 0.398 \\
\hline Lak of interest on ICT & 0.120 & -0.218 & 0.566 & 0.403 & -0.322 & 0.648 & 0.485 \\
\hline
\end{tabular}

Note: Major loadings for each item are bolded 


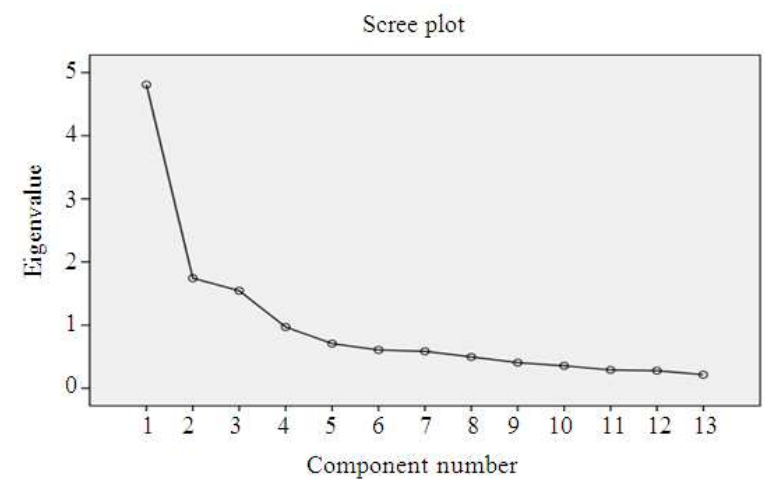

Fig. 3: Screeplot of the data

Table 16: Component correlation matrix

\begin{tabular}{|c|c|c|c|}
\hline Component & 1 & 2 & 3 \\
\hline 1 & 1.000 & -0.193 & 0.425 \\
\hline 2 & -0.193 & 1.000 & -0.143 \\
\hline 3 & 0.425 & -0.143 & 1.000 \\
\hline
\end{tabular}

Extraction Method: Principal Component Analysis; Rotation Method: Oblimin with Kaiser Normalization.

Table 17:Monte carlo PCA for parallel analysis

\begin{tabular}{|c|c|c|c|}
\hline $\begin{array}{l}\text { Eigenvalue \# } \\
\text { Dev }\end{array}$ & \multicolumn{2}{|c|}{ Random eigenvalue } & Standard \\
\hline 1 & \multicolumn{2}{|l|}{1.3681} & 0.0481 \\
\hline 2 & \multicolumn{2}{|l|}{1.2701} & 0.0383 \\
\hline 3 & \multicolumn{2}{|l|}{1.2015} & 0.0319 \\
\hline 4 & \multicolumn{2}{|l|}{1.1413} & 0.0284 \\
\hline 5 & \multicolumn{2}{|l|}{1.0857} & 0.0226 \\
\hline 6 & \multicolumn{2}{|l|}{1.0361} & 0.0244 \\
\hline 7 & \multicolumn{2}{|l|}{0.9898} & 0.0229 \\
\hline 8 & \multicolumn{2}{|l|}{0.9399} & 0.0243 \\
\hline 9 & \multicolumn{2}{|l|}{0.8960} & 0.0256 \\
\hline 10 & \multicolumn{2}{|l|}{0.8481} & 0.0249 \\
\hline 11 & \multicolumn{2}{|l|}{0.7992} & 0.0232 \\
\hline 12 & \multicolumn{2}{|l|}{0.7440} & 0.0285 \\
\hline 13 & \multicolumn{2}{|l|}{0.6803} & 0.0312 \\
\hline \multicolumn{4}{|c|}{$\begin{array}{l}\text { Analysis@2000, } 2010 \text { by Marley W. Watkins. All rights } \\
\text { reserved;Version 2.5; 5/4/2012 4:24:41 PM; Number of variables: } \\
\text { 13; Number of subjects: } 297 \text {; Number of replications: } 100\end{array}$} \\
\hline \multicolumn{4}{|c|}{$\begin{array}{l}\text { Table 18: Comparison of eigenvalues from PCA and criterion } \\
\text { values from parallel analysis }\end{array}$} \\
\hline $\begin{array}{l}\text { Component } \\
\text { number }\end{array}$ & \multicolumn{3}{|c|}{$\begin{array}{lll}\text { Actual eigenvalue } & \text { Criterion value from } & \\
\text { from PCA } & \text { parallel } & \text { analysis } \\
\text { Decision } & & \end{array}$} \\
\hline 1 & \multicolumn{2}{|c|}{$\begin{array}{ll}4.808 & 1.3681\end{array}$} & accept \\
\hline 2 & \multicolumn{2}{|c|}{$\begin{array}{ll}1.743 & 1.2701\end{array}$} & accept \\
\hline 3 & \multicolumn{2}{|c|}{$\begin{array}{ll}1.544 & 1.2015\end{array}$} & accept \\
\hline
\end{tabular}

\section{DISCUSSION}

Descriptive statistics: Table 3 presents the frequency and percentage for the respondent's years of experience; $23.5 \%$ has $1-5$ years of experience; $6-10$ years of experience has 33.3\%, 11-20 years of experience have $31.3 \%$; those that have $21-30$ years of experience are only $8.8 \%$ and those with over 30 years are $3.1 \%$. Contractors with little years of experience has the highest percentage because they are always available on site coordinating and monitoring construction works, while those having more than 30 years working experience are not available due to the nature of their work is more of managerial than site works.

Table 4 presents the frequency and percentage of the respondent's category; $2.0 \%$ are group a contractors, $4.0 \%$ are group B contractors, $20.2 \%$ and $73.7 \%$ are group $\mathrm{C}$ and $\mathrm{D}$ contractors respectively. The categories are divided based on the size of a project that the contractor's construction industry registered with Federal Registration Board of Nigeria (FRBN) capable to carried out, under category A (up to N2million), category B (N2million - N25million), category C (N25million - N100million) and category $\mathrm{D}$ (Above N100million). Only 2.0\% of the contractors belong to Category A because its contract sum is only up to $\$ 2$ million which is more of maintenance work they are doing. Contractors in category $\mathrm{D}$ have the highest percentage for the reason that most of the construction activities in the federal capital are executed in $\mathrm{N100millions}$ of naira, with little ones around $\mathrm{N} 25$ million for category B and C.

Table 5 presents the frequency and percentage of the respondent's level of education; $8.4 \%$ of the respondents has $\mathrm{PhD}, 9.5 \%$ Msc, $16.9 \%$ Bsc, $36.1 \%$ Diploma, $28.7 \%$ Certificate and $0.3 \%$ are secondary leavers. This result shows that those that acquired little in educational level (such as diploma with $36.1 \%$ ) goes into construction business more than those that are highly educated (such as $\mathrm{PhD}$ holders with $8.4 \%$ ), while an insignificant number of contractors possess secondary school certificate.

Table 6 presents the frequency and percentage of the number of staff in the respondent's construction industry; $39.2 \%$ of the industries have less than 50 staffs, $32.3 \%$ of the industries have in-between 50100 staffs, $17.9 \%$ has between $100-500$ staffs and $10.7 \%$ of the industries have more than 500 staffs. These results is showing that most of the construction industries are having staff less than 50 and those that has more staff are not more than $10 \%$.

Table 7 presents the summary of items statistics with grand mean of 3.83 for the construct, which show they are effective and inter-item correlation of 0.29 this show a weak relationship. These means generally ICT innovation affects its acceptance for construction site management.Table 8 presents the Anova results for the constructs, with p-value less than 0.05 indicating a significant difference between the items. This means the acceptance or rejection of one item will not affect others. 
Table 9 presents the strength of the relationships between contractors in category A, B, C, and D, with a significant correlation between contractor $\mathrm{A}, \mathrm{C}$, and $\mathrm{D}$ at $0.004,0.006$, and 0.000 significance, and r-value of $0.74,0.72$, and 0.97 respectively. This is due to the fact that contractor A can employ contractor C and D as subcontractors. Also, the relationship between contractor B and contractors A, C, and D is very weak, with r-values of $-0.38,0.24$ and 0.18 respectively.

The reliability test results presented in Table 10 show that Cronbach's alpha for the entire construct is 0.831 , which is highly acceptable as reported by Hair et al. (1995); Sekaran and Bougie (2010) and Maiyaki and Mokhtar (2011). These results suggest that those constructs are reliable; they can be used to assess ICT innovation in the construction sector.

Figure 1 presents a histogram with a normality plot, which shows a bell curve that is assumed to be normally distributed. Based on that, it is considered normal.

The Fig. 2 presents a normal plot of the regression standardized residual plots which appear to be fairly acceptable as a representation of normality, as no considerable departure from the diagonal for the residuals plots is demonstrated (Hair et al., 1995).

Factor analysis: For this analysis 13 positive and negative items of the questionnaire were subjected to Principal Components Analysis (PCA) using SPSS version 17.0. The suitability of the data for factor analysis was assessed; Table 11 presents correlation matrix which revealed that 85 out of 169 has a coefficient of 0.3 and above, which means factor analysis can be used in this study.

Table 12 presents the Kaiser-Meyer-Olkin (KMO) value of 0.83 , exceeding the recommended value of 0.6 (Kaiser 1970, 1974) and Bartlett's test of sphericity (Bartlett 1954) revealed a statistical significance supporting the factorability of the correlation matrix.

In Table 13 the principal components analysis revealed the presence of three components with eigenvalues exceeding 1, explaining $36.99 \%$, $13.41 \%$ and $11.88 \%$ of the variance respectively, with a total of $62.27 \%$ variance. That means these factors are the ones that has high effect on ICT innovation for construction site management.

An inspection of the screeplot in Fig. 3 revealed a sudden and continuous change after the third component. Therefore only components above this point are retained. These was also supported by the results of parallel analysis (Table 17), which showed only three components with eigenvalues exceeding the corresponding criterion values for a randomly generated data matrix of the same size (13 variables $\times 297$ respondents).

Table 14 is component matrixes presenting unrotated loadings of each of the items on the three components above 0.4 are loaded mostly on the first component, while very few items on the second and third components respectively. Which means component 1 are more effective and component 3 are less effective.

Table 15 presents a pattern matrix which shows the items loadings on three factors with six items loading above 0.3 on component 1 , four items loading on component 2 and five items on component 3. Since each component has more than three items loading we consider this solution optimal. Also, the items that positively affect the ICT innovation are under component 1 , while those that negatively affect the ICT innovation are under component 3. In addition, the structure matrix too present the strength of the correlation between the factors is higher under component 1 , followed by component 3 , then component 2. These means the items that have higher loadings in component 1 contribute positively to the ICT innovation, while the items with higher loadings under component 3 have negative effect to the ICT innovation for the construction site management.

Table 16 presents component correlation, whereby there was a weak negative correlation between factor one and two (-0.19) and between factor two and three (-0.14) and a weak positive correlation between factor one and three (0.43). These means each item is independent they did not influence each other.

Table 17 presents Monte Carlo principal component analysis for parallel analysis which is still showing items 1, 2 and 3 has the highest random eigenvalue in the parallel analysis, as it is compared on Table 18 with the actual eigenvalue from PCA; they are all less than the initial eigenvalue which makes it acceptable.

\section{CONCLUSION}

Based on the results presented contractors agreed that ICT innovation is very effective for construction site management. The factors that contribute to its effectiveness were found to be: awareness about the benefits of the ICT, knowledge of the ICT concept and exposure to the ICT devices. While those factors 
that negatively affects the ICT innovation are: operational difficulties of the ICT devices, security features of the ICT devices, lack of purposely made ICT devices and lack of interest to use ICT devices.

Therefore, this study proof that, the aforementioned factors contributes immensely toward ICT innovation acceptance for the construction site management and it provides an empirical evidence that the factors has effect on ICT adoption. Hence, conclusion could be reached that, ICT innovation helps in fast-tracking project activities, it does reduce risk and time overrun and in general it enhances productivity and efficiency. But, there is need of specific ICT devices for construction activities, because of its heterogeneous nature.

\section{REFERENCES}

Bartlett, M.S., 1954. A note on the multiplying factors for various $\chi^{2}$ approximations. J. Royal Stat. Soc., 16: 296-298.

Choi, N., D.R. Fuqua and B.W. Griffin, 2001. Exploratory analysis of the structure of scores from the multidimensional scales of perceived self-efficacy. Educ. Psychol. Measu., 61: 475489. DOI: 10.1177/00131640121971338

Drucker, P.F., 1993. Post-Capitalist Society. 1st Edn., HarperBusiness, New York, ISBN-10: 0887306209, pp: 232.

Egmond, E.L.C. and W. Ligny, 2005. Successful Industrialisation, Innovation and Prefabrication in construction.Proceedings of 11th Joint CIB International Symposium, Combining Forces. Advancing Facilities Management and Construction Through Innovation, Undestanding Construction Business and Companies in the New Millenium, (UCBCNM' 05), Fillandia Hall, Helsinki, Finland, pp: 415-426.

Hair, J.F., R.E. Anderson, R.L. Tatham and W.C. Black, 1995. Multivariate Data Analysis with Readings. 4th Edn., Prentice-Hall Englewood Cliffs, New Jeresy, ISBN-10: 0023490209 pp: 745.

Horn, J.L., 1965. A rationale and test for the number of factors in factor analysis. Psychometrika, 30: 179-185. DOI: 10.1007/BF02289447

Pallant, J., 2011. SPSS Survival Manual: A step by step guide to data analysis using the SPSS Program. 4th Edn., Allen and Unwin, ISBN-10: 9781742373928, pp: 345.

Kaiser, H.F., 1970. A second generation little jiffy. Psychometrika, 35: 401-415. DOI: 10.1007/BF02291817
Kaiser, H.F., 1974. An index of factorial simplicity. Psychometrika, 39: 31-36. DOI: 10.1007/BF02291575

Koskela, L. and R. Vrijhoef, 2000. The Prevalent Theory of Construction is a Hindrance for Innovation [Online].

Maiyaki, A.A. and S.S.M. Mokhtar, 2011. Determinants of customer behavioural responses: A pilot study. Int. Bus. Res., 4: 193-197.

Mottowa, I.A., Price, A.D.F. and Sher, W. 1999. The Introduction and Management of Innovative Construction Processes and Products. In: Proceedings of the 14th Annual ARCOM Conference, Sept. 9-11, UK., pp: 672-682.

Newman, M. and R. Sabherwal, 1996. Determinants of commitment to information systems development: A longitudinal investigation. MIS Q., 20: 23-54. DOI: 10.2307/249541

Osman, O., 2008. Emerging Governance and Economic Issues in Construction Industry in Malaysia. 1st Edn., Penerbit University Sains Malaysia, Pinang Malaysia, ISBN-10: 9789833986101 pp: 206.

Sekaran, U. and R. Bougie, 2010. Research Methods for Business: A Skill Building Approach. 5th Edn., John Willey and Sons, Chichester, ISBN10: 9780470744796 pp: 488.

Stober, J., 1998. The Frost Multidimensional Perfectionism Scale revisited: More perfect with four (instead of six) dimensions. Persona. Indiv. Diff., 24: 481-91. DOI: 10.1016/S01918869(97)00207-9

Tabachnick, B.G. and L.S. Fidell, 2007. Using Multivariate Statistics. 5th Edn., Pearson Education, Boston, ISBN-10: 0205465250, pp: 980.

Toole, T.M., 1998. Uncertainty and home builders' adoption of technological innovations. J. Construction Eng. Manage., 124: 323-323. DOI: 10.1061/(ASCE)0733-9364(1998)124:4(323) 